\title{
癩に於けるVitamin 製劑の治驗（第】報）
}

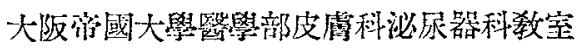

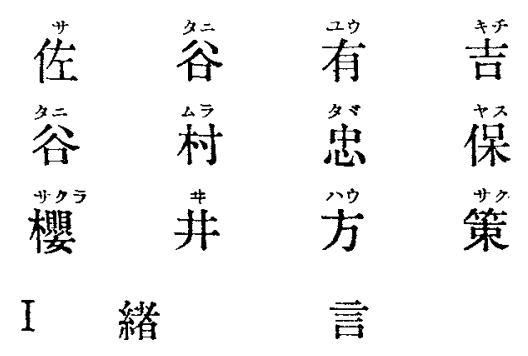

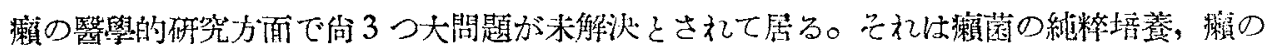

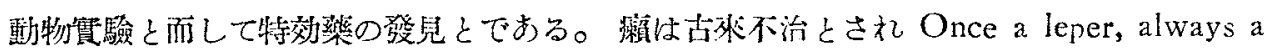

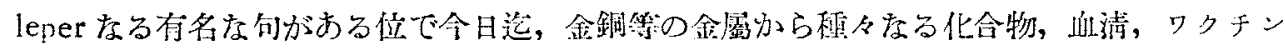

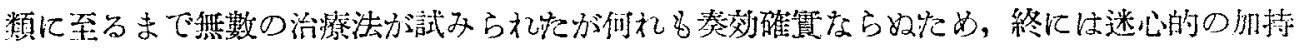

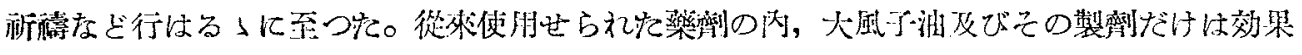

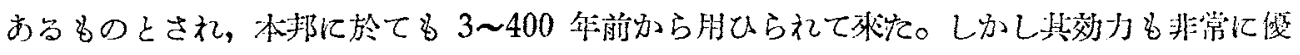

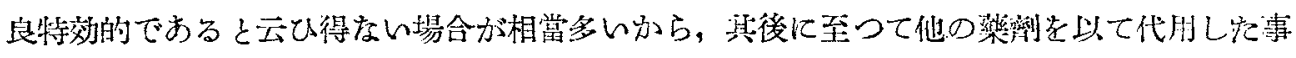

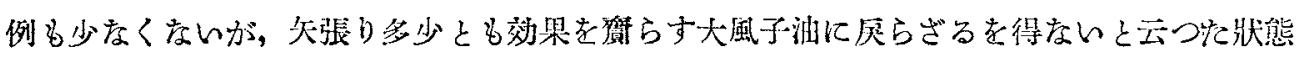
であつ范。

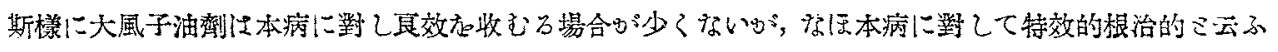

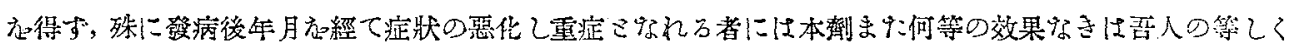

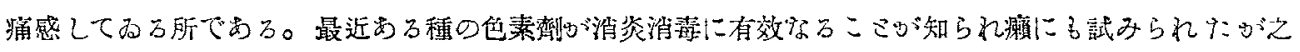

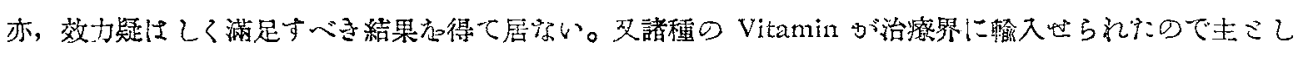

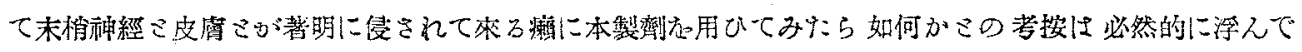

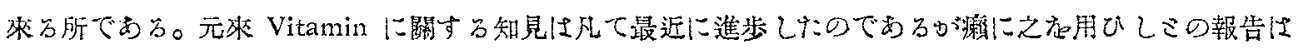
洵に卙了海外に於て Badger 及び Patrick, Villela, Gilberts, 本邦に於てば中條資俊, 安田忠次郎雨氏の

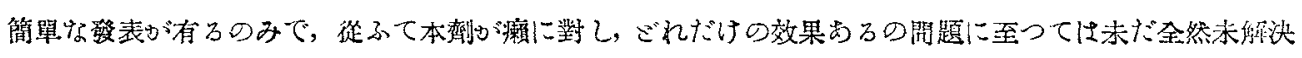

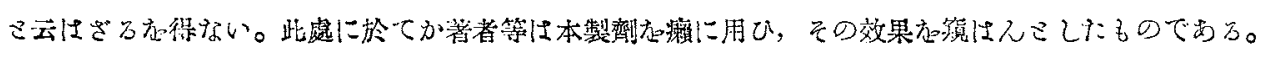

\section{II 藥确及び注射法}

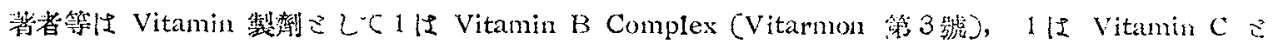
在用ひけ。

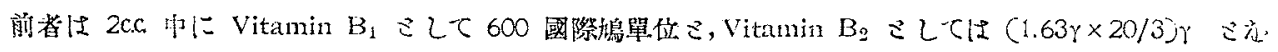

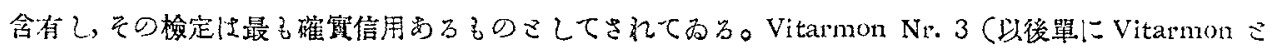
( 33 ) 


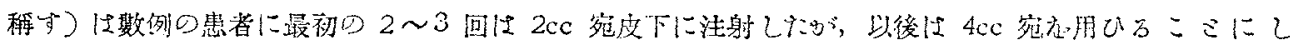

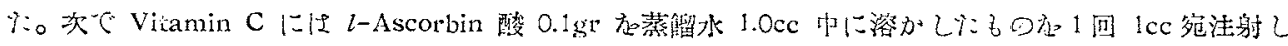
I:

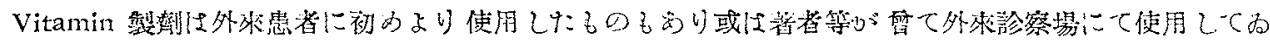

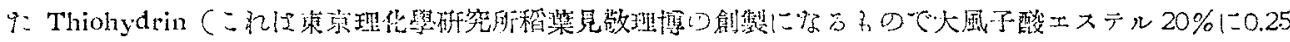

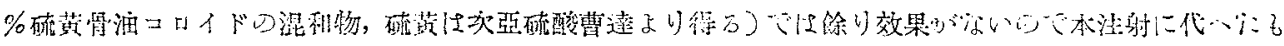

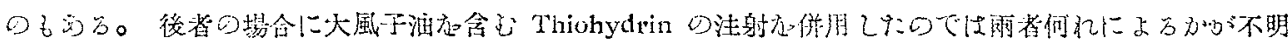

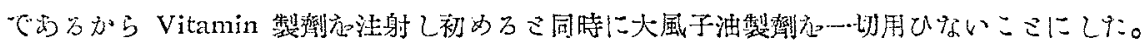

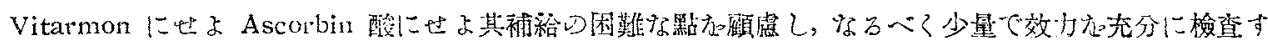

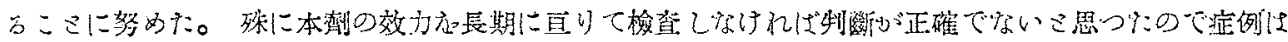

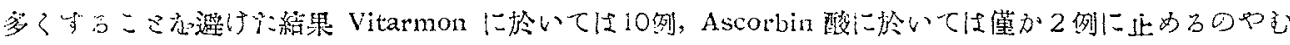
なき至つ\%:。

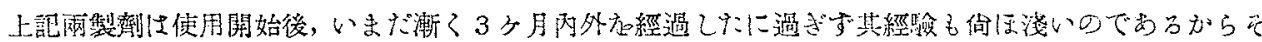

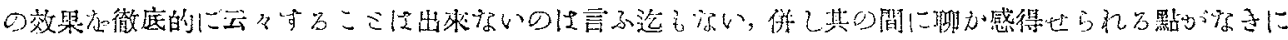

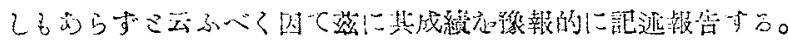

\section{III 實 驗 症 例}

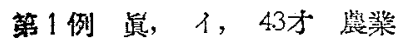

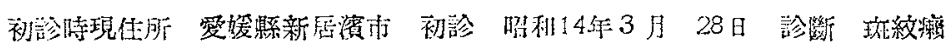

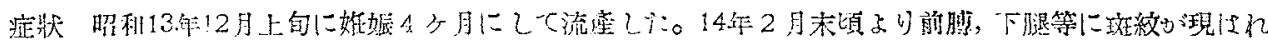

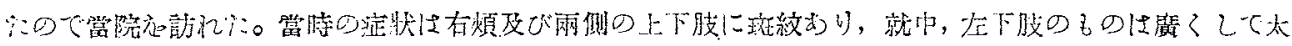

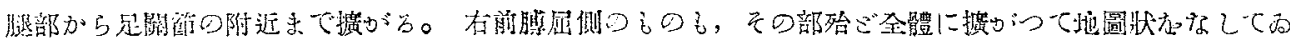

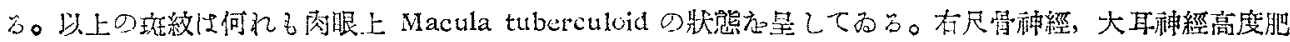
度，光田氏区歪独陽性。

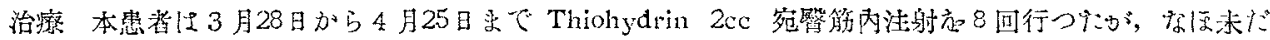

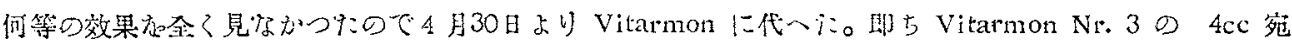

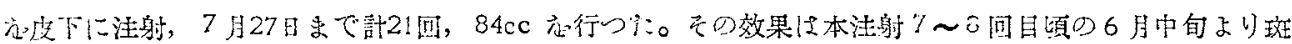

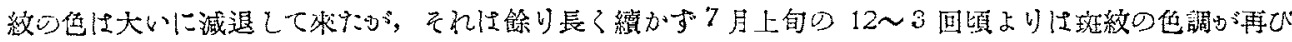

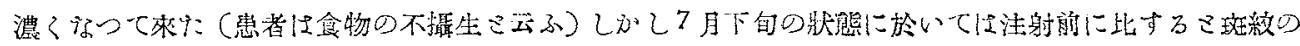

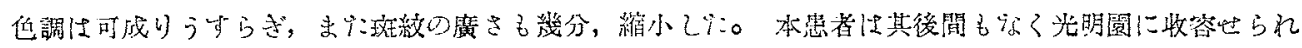

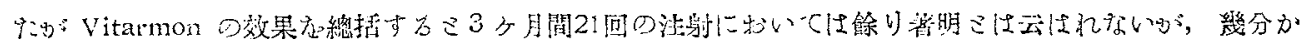

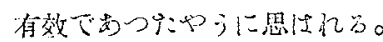

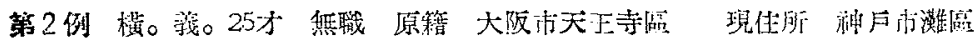

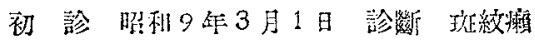




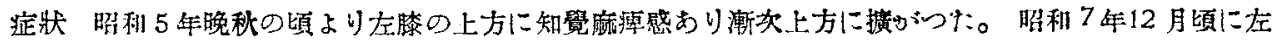

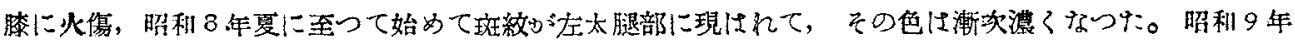

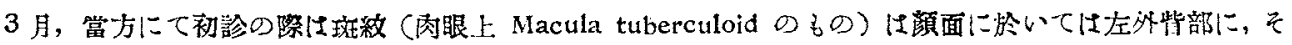

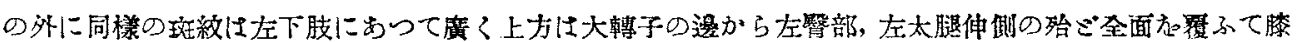

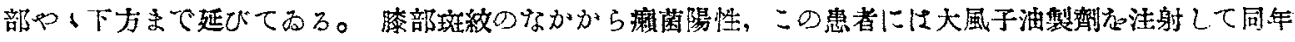

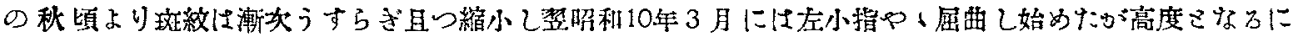

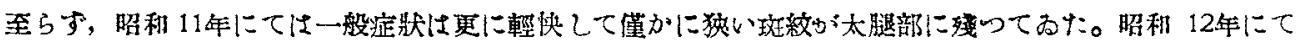

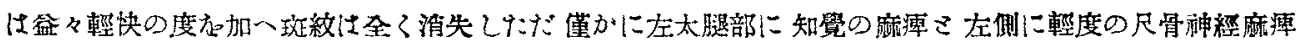

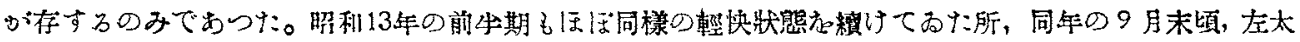

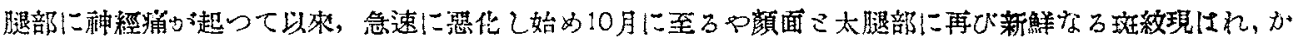

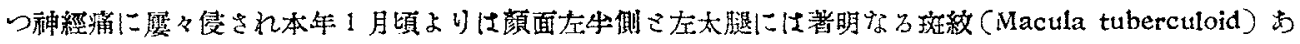

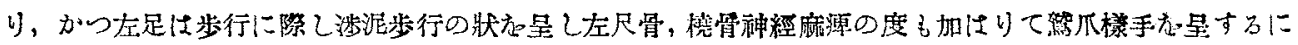

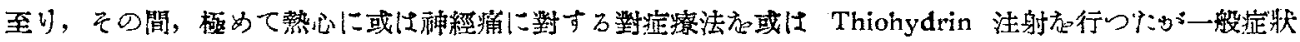

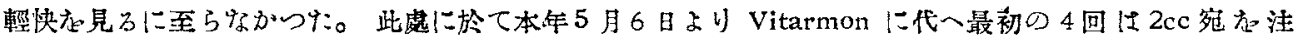

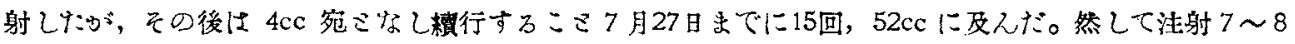

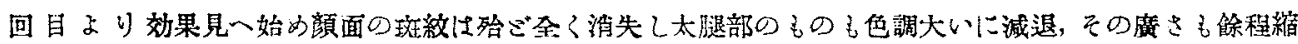

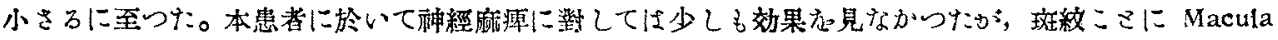

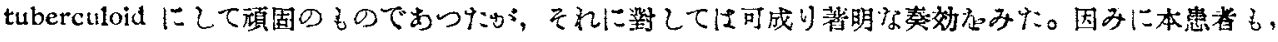
その啳間るなく光明園に牧容された。

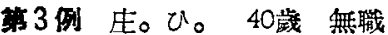

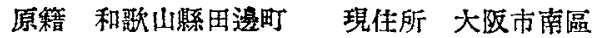

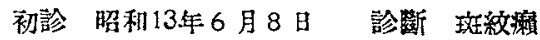

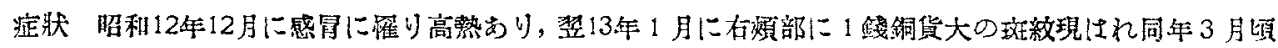

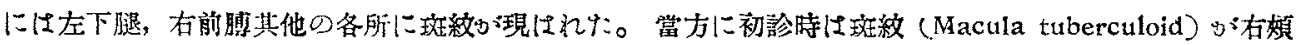

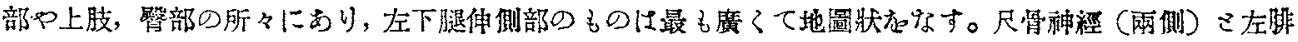

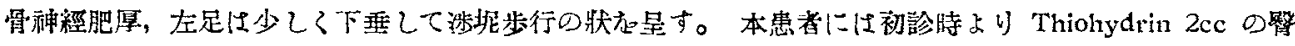

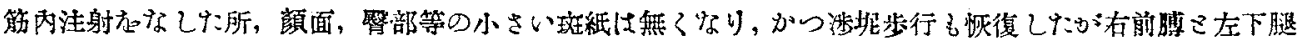
の玟粒は消失しなかつげ。依つて本年 5 月 2 日より Vitarmonに代一始めに2cc宛，25日よりは4cc宛

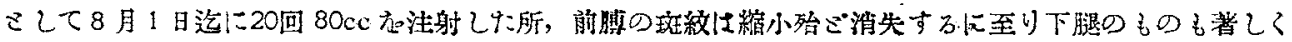

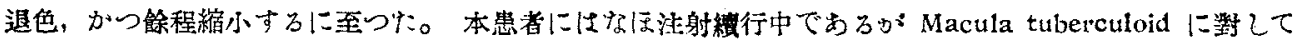
は之も相當顯者な效果交してるる。

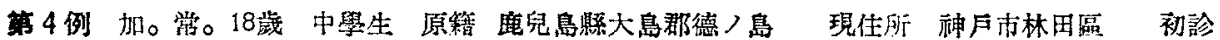
昭利14年6月29日 診斷 斑效濑

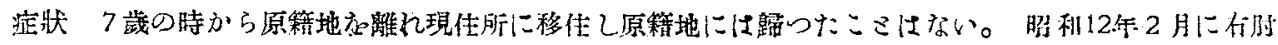
(35) 


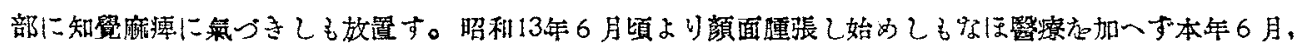

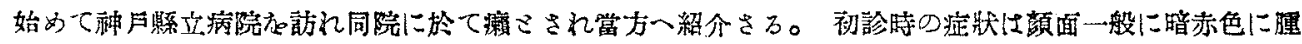

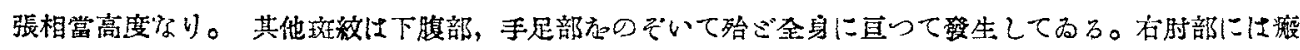

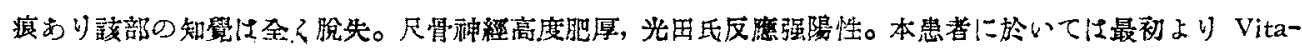

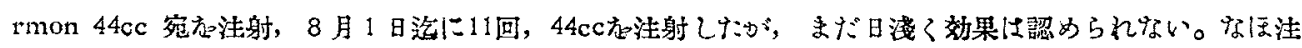

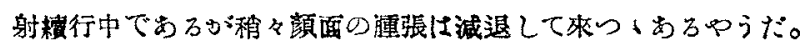

第 5 例 大。吾。29歲 職工 原籍 兵庫縣䀢磨郡 現住所 大阪甫大正區 初診昭和11年 7 月8 日 䛦斷 結節癞漫洞型

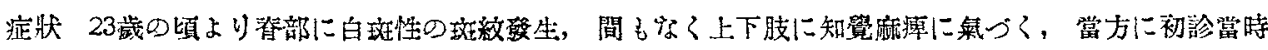

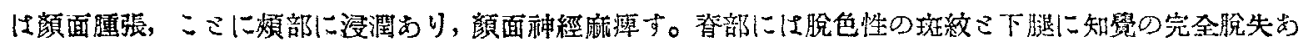

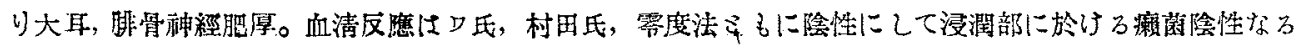

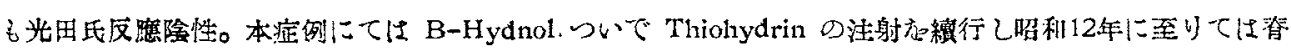

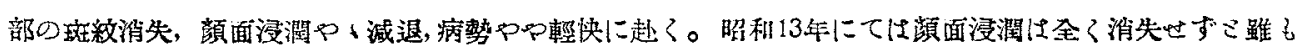

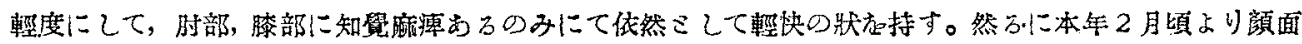

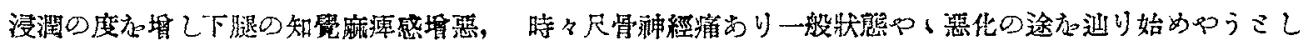

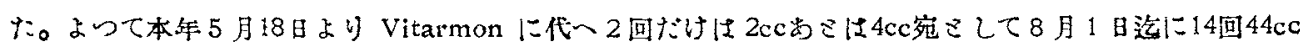

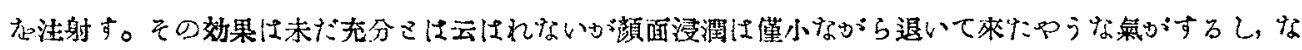

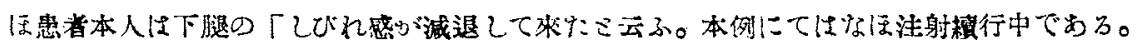

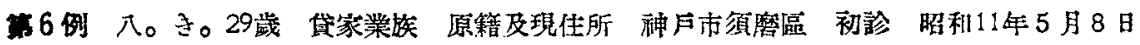

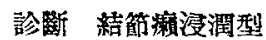

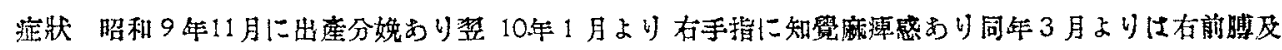

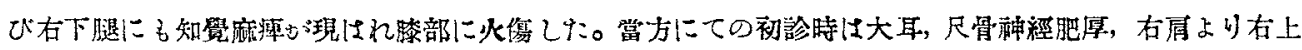

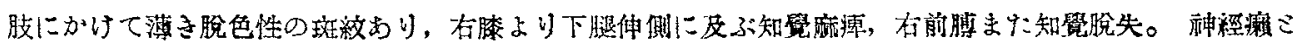

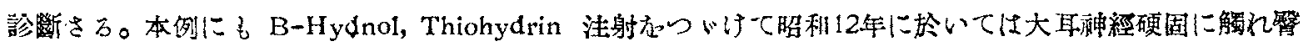

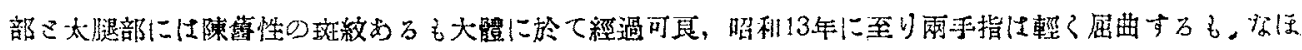

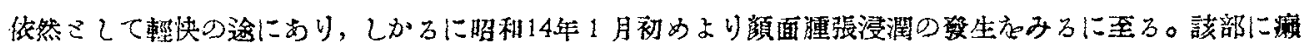

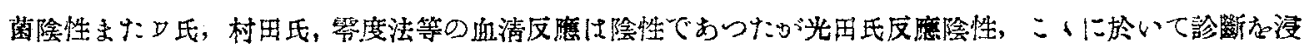

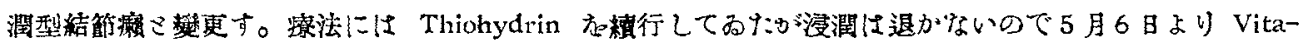

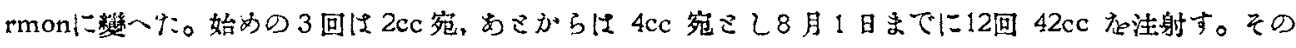

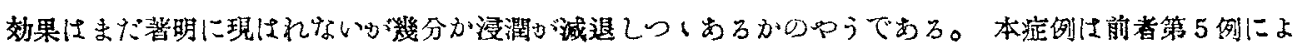
く似たものであり唒ほ注射繢行中でめる。

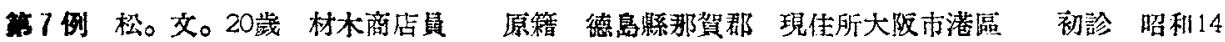
4. 1 月 8 日 䛦断 結箅㿎浸潤型

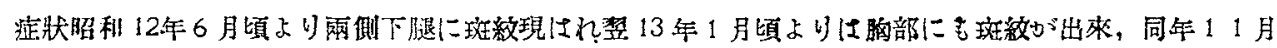




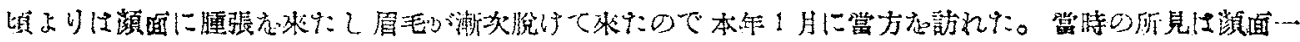

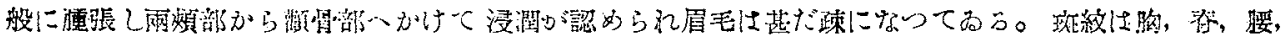

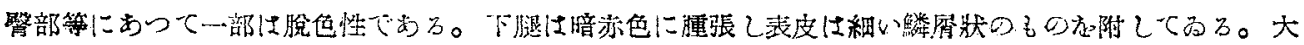

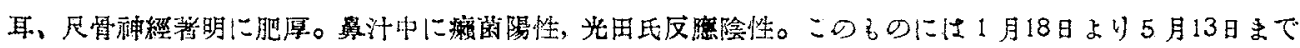

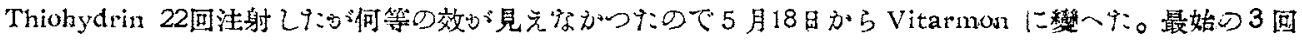

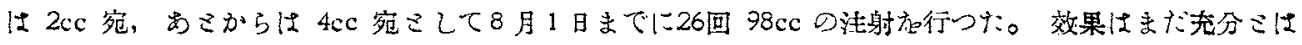

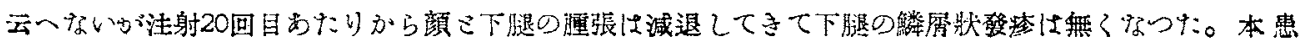

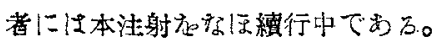

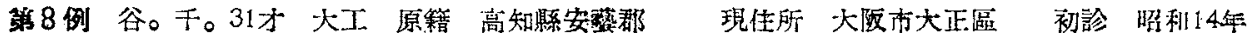

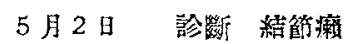

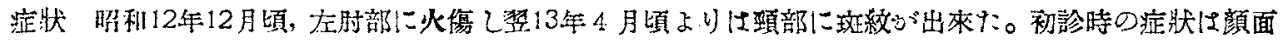

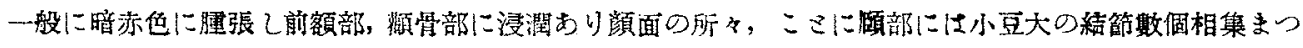

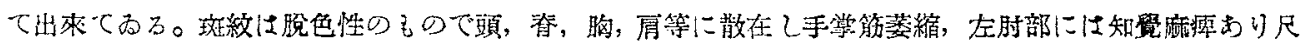

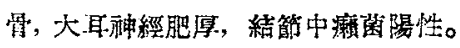

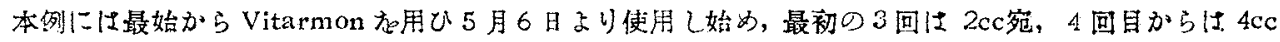

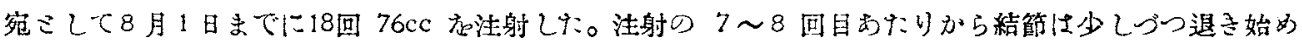

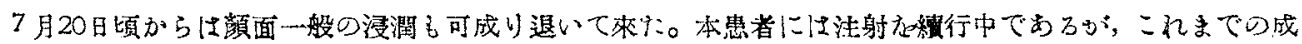

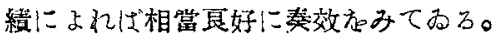

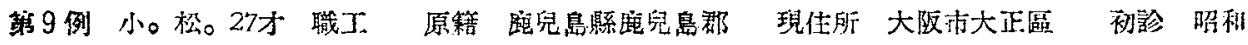

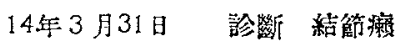

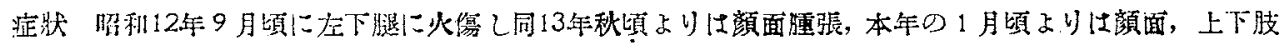

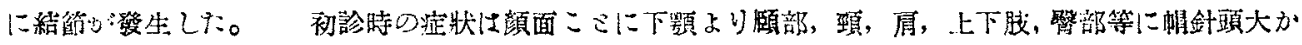

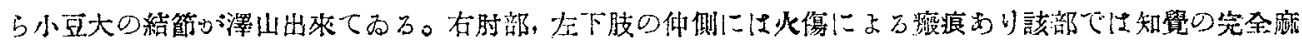

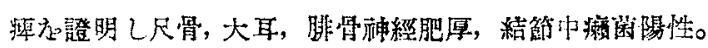

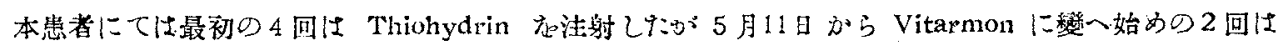

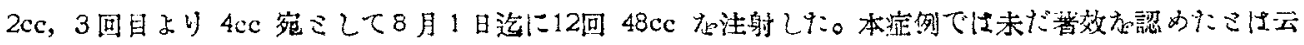

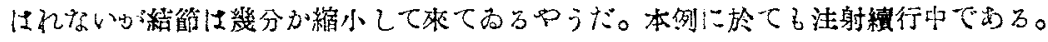

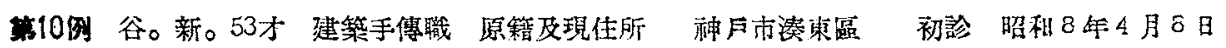
䓂斷 結節獭

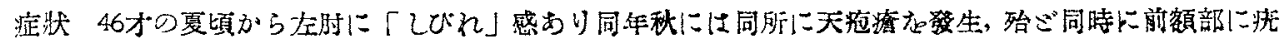

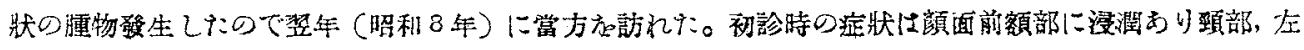

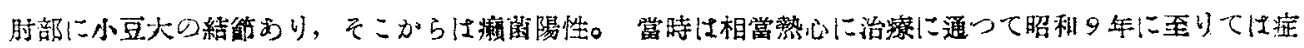

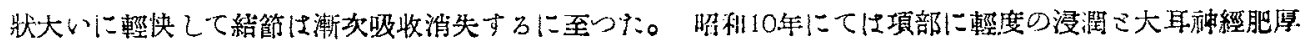

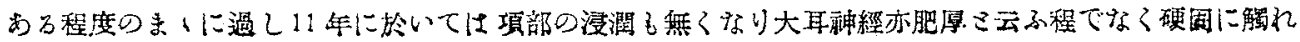




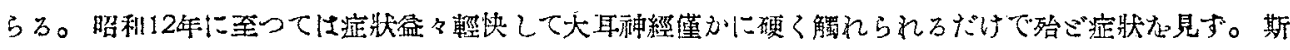

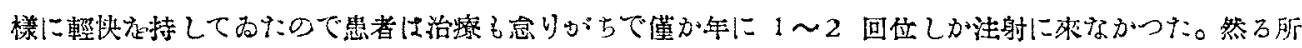

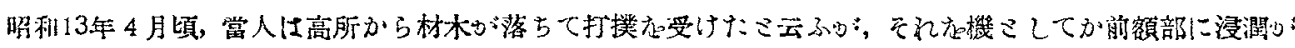

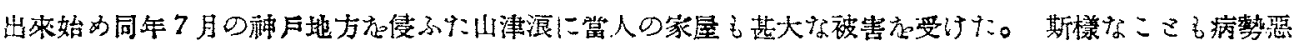

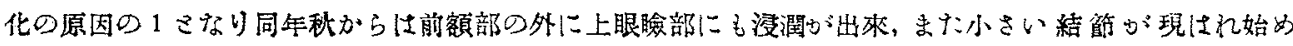

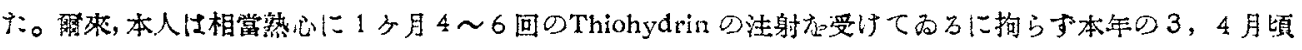

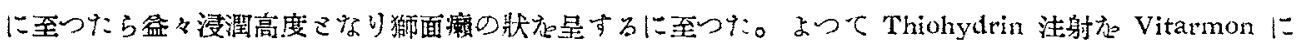

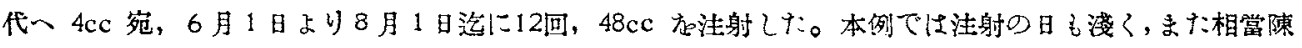

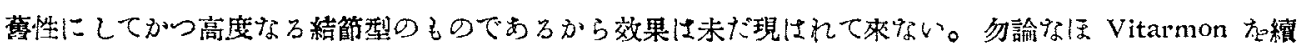
けて洼射して西吕。

\section{l-Ascorbin 酸を用Uし症例}

第 1 例 高。光。37才 職工 原籍三重縣多氣郡 現传所 大随市此花區 初診 昭科111年6月 5 日 診迦 結節癞浸润型

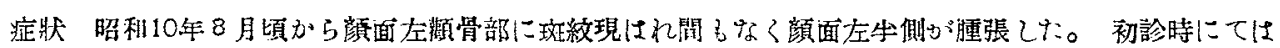

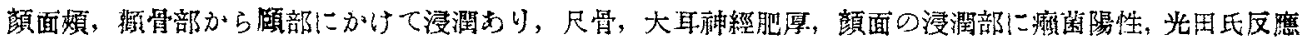
陰性。

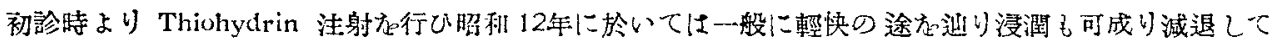

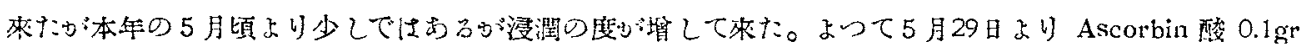

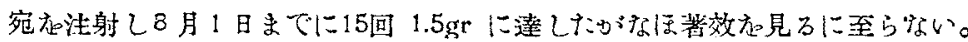

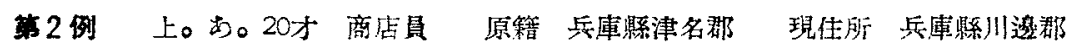

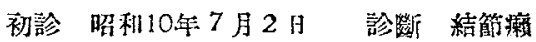

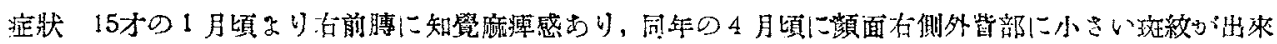

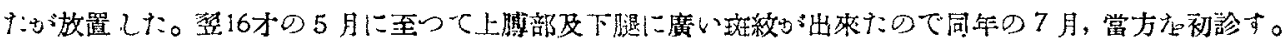

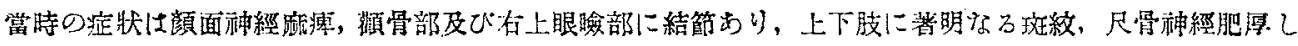

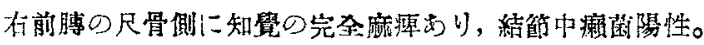

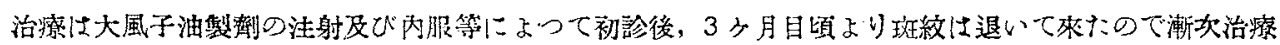

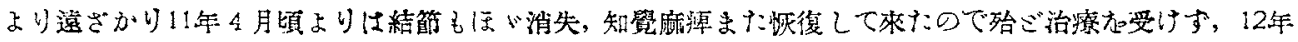

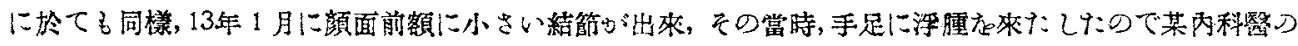

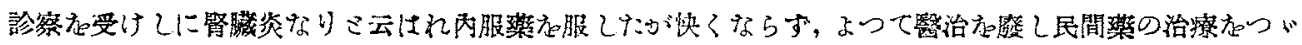

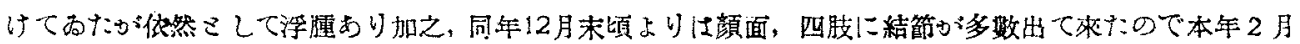

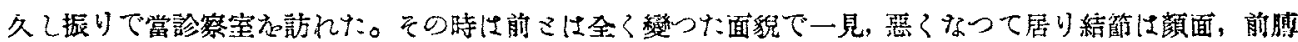

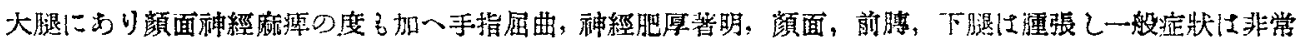
に塯琶してるな。

この者には本年 2 月から 5 月20日頃まで 1 ク月に5〜7回の都で Thiohydrin な注射してふたが何等 


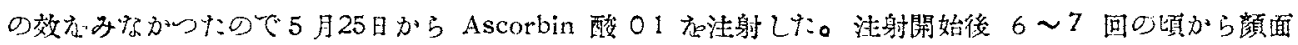

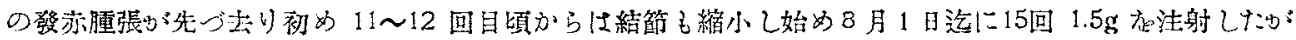

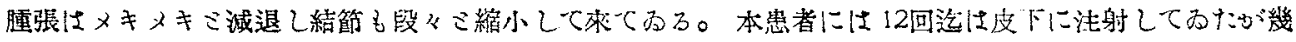

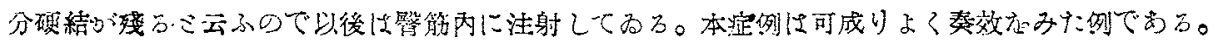

\section{IV 總括及び考挨}

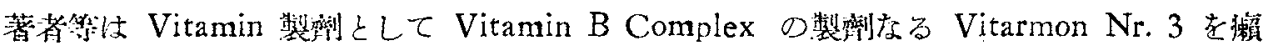

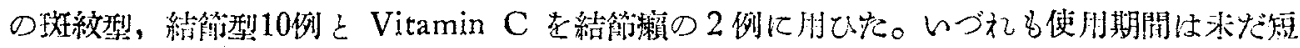

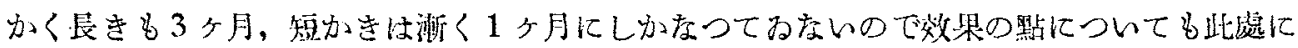
ハッキリしをことは可諭云はれないが，てれまでの成績老概括してみる。

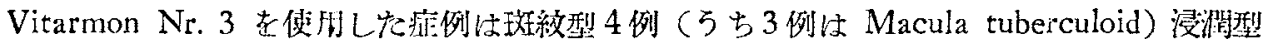

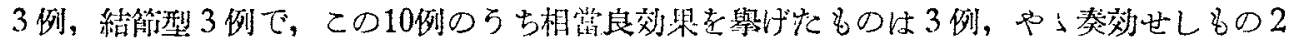
例，むとの 5 例は米效である。

Vitarmon 使 肘 症: 例

\begin{tabular}{|c|c|c|c|c|c|c|c|c|c|}
\hline 嫣 & 姓名 & $\begin{array}{l}\text { 年 } \\
\text { 路会 }\end{array}$ & 殓 & 聯; & 初診 年 月 日 & 使用其閻 & 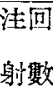 & & 錄 \\
\hline 1 & 直 1 & 43 & 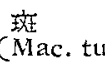 & $\begin{array}{l}\text { 紋 } \\
\text { ber) }\end{array}$ & 昭利14年 3 月28日 & & 21 & & 秒々秦效ス \\
\hline 2 & 涉㼁 & 25 & 同 & 上 & 炤利9年3月1日 & 同 & 15 & $52 \mathrm{cc}$ & 奏效 (Thiohydrin無效) \\
\hline 3 & 星ひ & 40 & 同 & 上 & 昭利13年 6 月 8 日 & 同 & 20 & $80 \mathrm{cc}$ & 奏效 (Thiohydrin無效) \\
\hline 4 & 抑掌 & 18 & 祀 紋 & 型 & 昭利14年 6 月 29 日 & 1 ク 月 & 11 & $44 \mathrm{cc}$ & 米效（最初引リ使用） \\
\hline 5 & 大觢 & 29 & 浸 潤 & 型 & 昭利!11年7月8日 & 2 方月4 & 14 & $44 \mathrm{cc}$ & 沫效 (Thiohydrin無效) \\
\hline 6 & 八表 & 29 & 同 & 上 & 昭利11年5月8日 & 32 月 & 12 & $42 \mathrm{cc}$ & 末效 (Thiohydrin然效) \\
\hline 7 & 松文 & 20 & 同 & 上 & 炤利14年 1 月 8 日 & 2 㭌 & 26 & $98 \mathrm{cc}$ & 稳々奏效 (Thiohydrin無效) \\
\hline 8 & 谷F & 31 & 結 節 & 型 & 炤利14年 5 月 2 日 & $3 ち$ 月 & 18 & $76 \mathrm{cc}$ & 奏效（最初引リ使用） \\
\hline 9 & 小松 & 27 & 同 & 上 & 昭利14.年 3 月31日 & 2 子月釉 & 12 & $48 \mathrm{cc}$ & 沫效 \\
\hline 10 & 谷新 & 53 & 同 & 上 & 翞利 8 年 4 月 8 日 & 2 万月 & 12 & $48 \mathrm{cc}$ & 未效 (Thiohydrin無效) \\
\hline
\end{tabular}

Ascorbin 酸 使 的 症 例

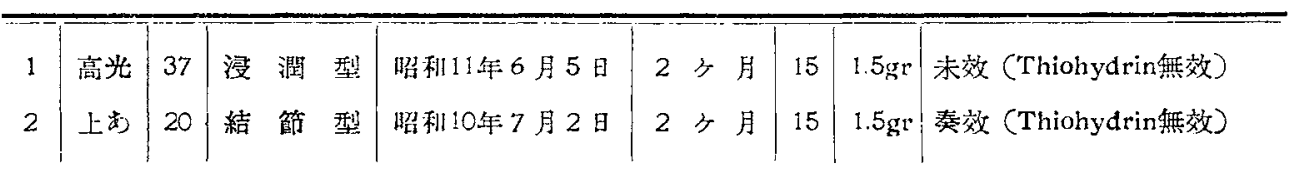

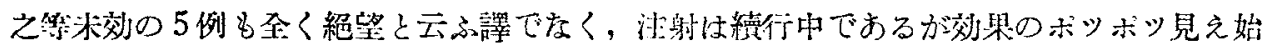

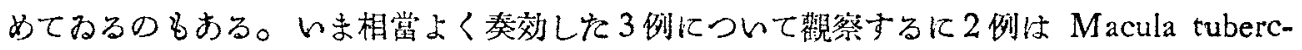




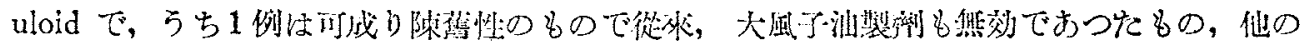

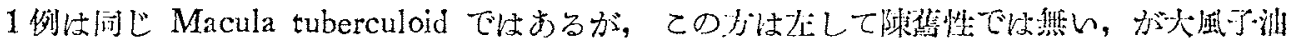

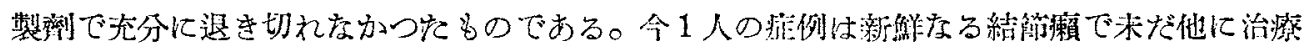

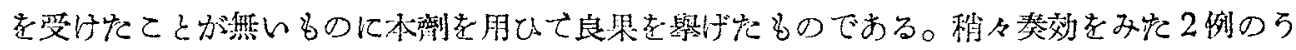

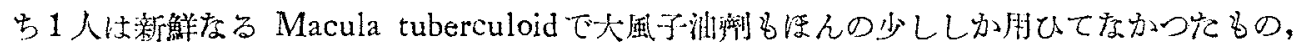

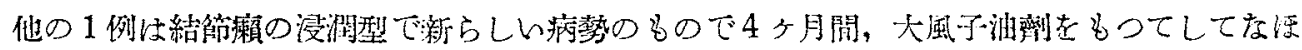

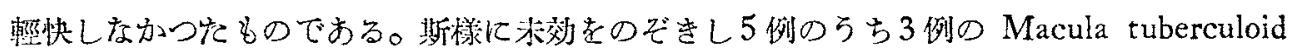
はすべて象に们教果をみてみる。よつてこ礼だけでの例では Vitarmon は Macula tuber

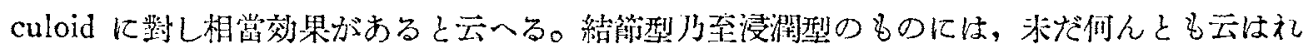
校。

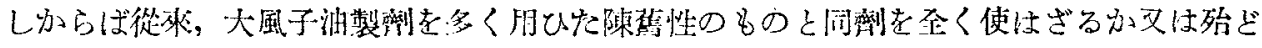

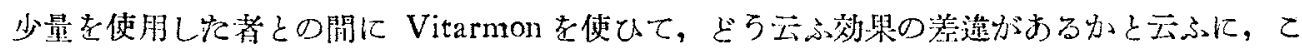

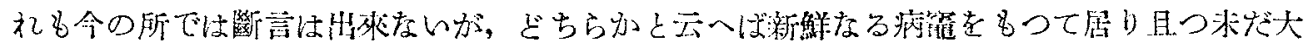

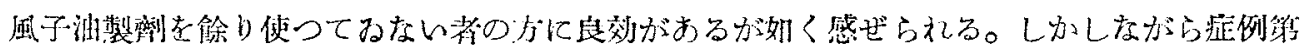

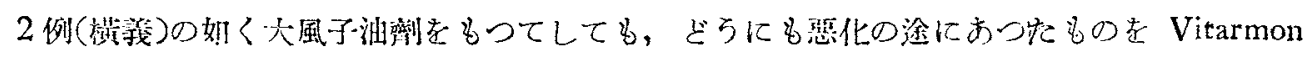

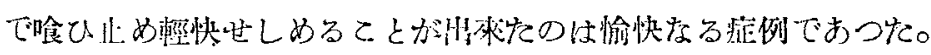

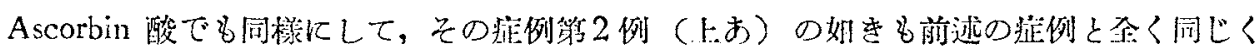

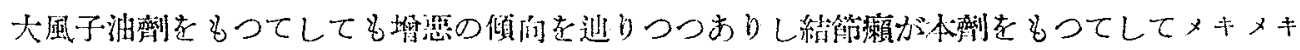

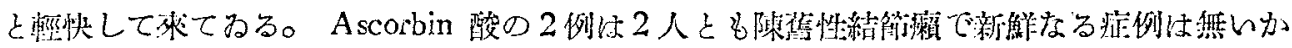
ら新斿しい者にどら效くか，それは全く分らない。

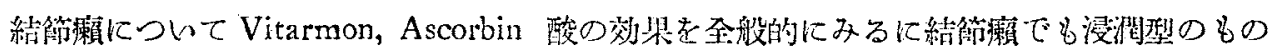

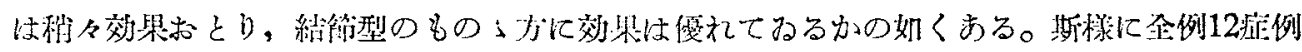

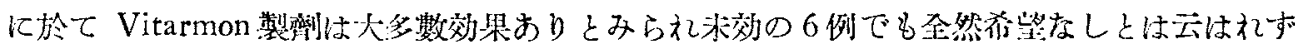
泚次效棵が見へて来つょおるかの姐き現狀である。

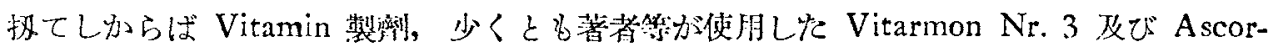

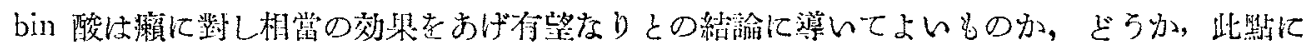

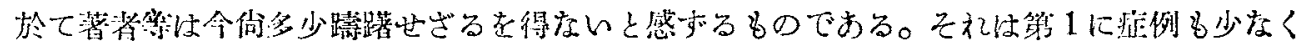

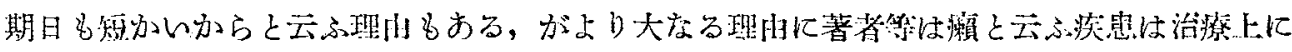

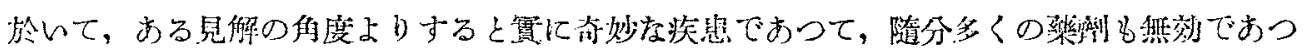

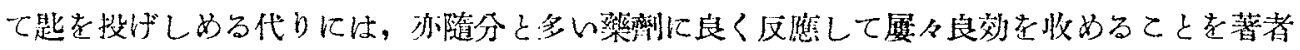

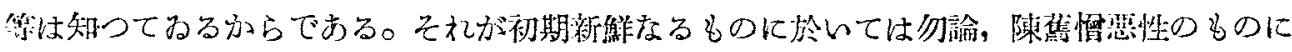

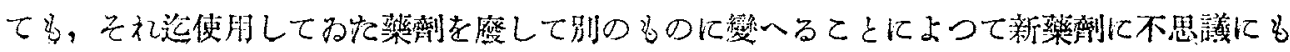




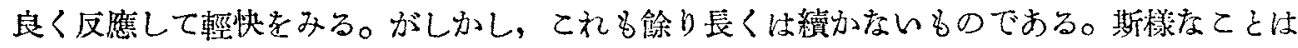

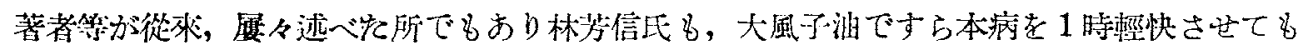

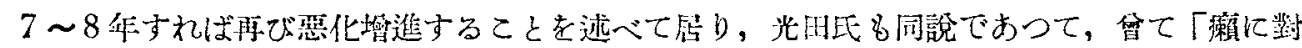

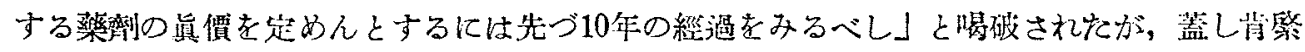
に價するものと著者采为信ずる。

Vitarmon 及び Ascorbin 酸は今迄の短日月の經驗に於いては多少とも有毞であるかの觀

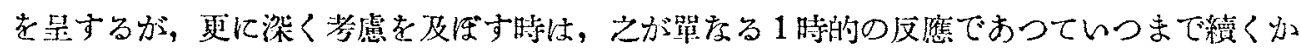

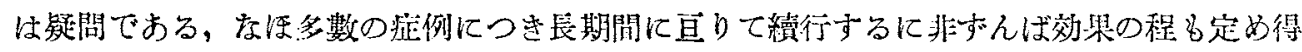

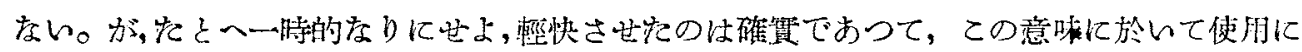

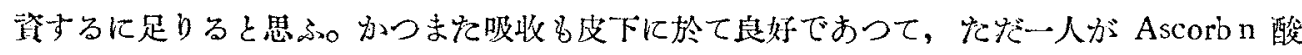

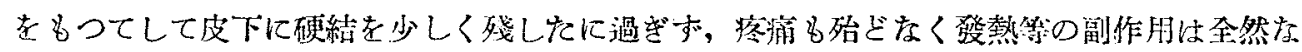

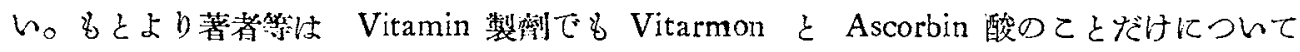

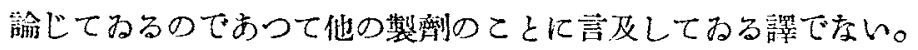

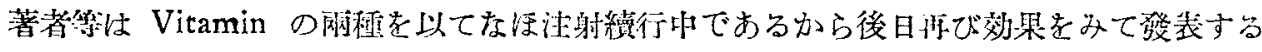

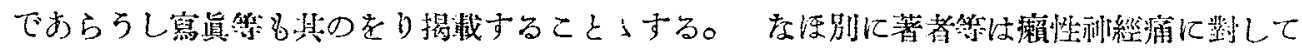

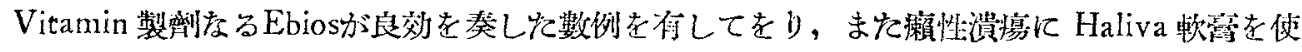
朋した經驗も准してるるが夫露も共に第2 報にゆづることにしやう。

\section{$\mathrm{V}$ 結 諭}

1) Vitarmon Nr.3 は Macula tuberculoid に對して相賞良效を奏す。

2) 极劑は結節型のものにも稍々奏效す方。

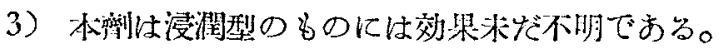

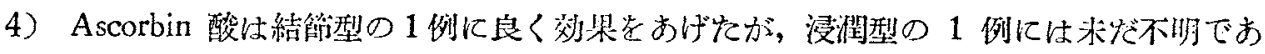
万。

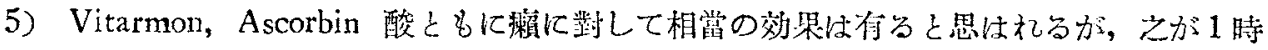
的のものなりや否やは更に將來の賽驗に侯を奴ばをらぬ。

(嚾利14年7月25日受简)

文献

(次號に(9づる) 


\title{
KLINISCHE STUDIEN ÜBER DEN EINFLUSS VON VITAMINPRÄPARATEN AUF DIE LEPRA.
}

\author{
I. Mitteilung.
}

Von

\section{Dr. Yukichi Satani, Dr. Tadayasu Tanimura und Dr. Hosaku Sakurai. \\ [Aus dex Dermato-Urologischen Klinik der Kaiserlichen Universität zu Osaka \\ (Direktor: Prof. Dr. Y. Satani)]}

Wir behandelten 12 Leprakranke mit Vitaminpräparaten, und zwar bekamen 10 von diesen komplexes Vitamin B (Vitarmon Nr. 3) und 2 Vitamin C (1-Askorbinsäure Loche). Die Resultate lassen sich wie folgt zusammenfassen :

1) Komplexes Vitamin B erwies sich als mehr oder weniger deutlich wirksam bei tuberculoiden Maculae.

2) Ziemlich gute Dienste leistete es auch bei der Knotenform der Lepra.

3) Bei der Infiltrationsform war Vitamin B dagegen ohne jede Wirkung.

4) Die l-Askorbinsäure erwies sich bei einem Fall von Lepra tuberosa als sehr wirksam, während bei einem Fall der Infiltrationsform kein Erfolg festzustellen war.

5) $\mathrm{Ob}$ die Wirkung der Vitamine auf die Lepra nur eine vorübergehende ist oder nicht, muß vorläufig noch dahingestellt bleiben. Zur Klärung dieser Frage sind erst noch weitere Untersuchungen nötig. 